Review

\title{
Management of Sulfide-Bearing Waste, a Challenge for the Mining Industry
}

\author{
Björn Öhlander ${ }^{1, *}$, Terrence Chatwin ${ }^{2}$ and Lena Alakangas ${ }^{1}$ \\ 1 Department of Geosciences, Luleå University of Technology, SE-971 87 Luleå, Sweden; \\ E-Mail: lena.alakangas@1tu.se \\ 2 International Network for Acid Prevention, 2105 Oneida Street, Salt Lake City, UT 84109, USA; \\ E-Mail: terrence.chatwin@inap.com.au
}

* Author to whom correspondence should be addressed; E-Mail: bjorn.ohlander@1tu.se;

Tel.: +46-920-491396; Fax: +46-920-491199.

Received: 13 December 2011; in revised form: 3 January 2012 / Accepted: 2 February 2012 /

Published: 8 February 2012

\begin{abstract}
Oxidation of iron sulfides in waste rock dumps and tailings deposits may result in formation of acid rock drainage (ARD), which often is a challenging problem at mine sites. Therefore, integrating an ARD management plan into the actual mine operations in the early phases of exploration, continuing through the mine life until final closure might be successful and decrease the environmental impact. A thorough characterization of ore and waste should be performed at an early stage. A detailed knowledge of mineralogical composition, chemical composition and physical properties such as grain size, porosity and hydraulic conductivity of the different waste types is necessary for reliable predictions of ARD formation and efficiency of mitigation measures. Different approaches to prevent and mitigate ARD are discussed. Another key element of successfully planning to prevent ARD and to close a mining operation sustainably is to engage the mine stakeholders (regulators, community and government leaders, non-governmental organization (NGOs) and lenders) in helping develop and implement the ARD management plan.
\end{abstract}

Keywords: sulfide oxidation; acid rock drainage; tailings management; waste rock management 


\section{Introduction}

There has been a tremendous development of reducing the environmental footprint of mining the last several decades, but mining operations may still have detrimental effects on soil, water and biota. Mining operations generally require large areas of land, and associated conflicts arise that are primarily related to competing land uses. The mining industry is also a major energy consumer. In addition, a substantial amount of fossil fuel is used. Leakage of the nutrient nitrogen from undetonated explosives and from cyanide leaching for gold extraction is common. Dust and noise problems are common at mine sites. However, these effects occur only as long as a mine is active. The major potential long-term environmental effect of mining is formation of acid rock drainage (ARD) in sulfide-bearing mine waste, which can last for hundreds or even thousands of years (e.g., [1,2]). Volcanogenic massive base metal deposits contain a few percent of the valuable metals [3], and thus more than $90 \%$ of the ore will be waste after processing. Large porphyry copper ores often have an average copper concentration of less than $1 \%$, resulting in that more than $99 \%$ of the ore will be waste after processing [4]. Gold is mined in deposits with a grade as low as a few grams per tons [5]. These examples show that the major parts of ores thus will be waste. In some mines, large amounts of wall rock have to be mined to get access to the ore, which results in waste rock deposits.

The Swedish biologist Carl von Linné observed early in the 18th century that the Falu River in south central Sweden was polluted by drainage waters from the Falu copper mine. However, it was only a few decades ago that ARD was recognized as a cause of serious damage to the environment. During the last 30 years, considerable effort has been invested worldwide by researchers, mining companies and environmental authorities to understand the fundamental processes occurring in weathering deposits of mine waste, and to develop cost-efficient technologies to prevent and control ARD [1,2].

ARD may be formed in waste deposits containing Fe-sulfides such as pyrite $\left(\mathrm{FeS}_{2}\right)$ and pyrrhotite $\left(\mathrm{Fe}_{1-x} \mathrm{~S}\right.$, where $\left.x=0-0.125\right)$, if the acid producing capacity of the Fe-sulfides is larger than the buffering capacity of carbonates in the waste (e.g., [1]). This ARD is often rich in heavy metals and metalloids. Conventional mining activities, in-situ mining and bio-mining not considered, generate two main types of wastes, which both may contain sulfide minerals. These waste types are waste rock (dominated by coarse material) that is removed to reach the ore, and finely ground tailings generated during the ore processing. When waste that contains Fe-sulfides is exposed to oxygen and moisture, these sulfides are oxidized to free $\mathrm{Fe}^{2+}$ ions and sulfate with the concurrent microbial catalyzed production of acidity. The oxidation rate depends on several factors including oxygen availability, temperature, $\mathrm{pH}$, bacterial activity and surface area of pyrite grains [6-8]. This acidification enhances the mobility of heavy metals and other elements occurring in the mining wastes (e.g., [1,6,9,10]. The free $\mathrm{Fe}^{2+}$ ions may further oxidize and precipitate as Fe-hydroxides generating further acidification, which often occurs in the recipient downstream. Waste from $\mathrm{Cu}, \mathrm{Zn}, \mathrm{Pb}$, and $\mathrm{Au}$ mining usually contain Fe-sulfides, in contrast to waste from Fe-oxide mining. Oxidation of the Fe-sulfides in alkaline environments results in neutral drainage waters, with elevated concentrations of sulfate but most cations are secondarily retained by adsorption to mineral surfaces at $\mathrm{pH}>6$, while the concentration of anions may remain high [1]. 
The minerals industry is well aware of the potential adverse issues relating to Acid Rock Drainage. The costs carried by many mining companies to cover current liabilities are a clear indication of the gravity of the problem. To address these problems the International Network for Acid Prevention (INAP) has developed the GARD Guide, an internet-based best practices guide to prevent and mitigate the formation of acid, neutral and saline drainages from mining operations [2]. This guide was developed not only for mine operators, but for all minerals-industry stakeholders including regulators, financiers, communities and non-governmental organization (NGO's). In this paper, we will describe proven practices that prevent and mitigate ARD in mining and other excavations, mainly based on the GARD Guide [2], and the Swedish MiMi-programme [1].

\section{Results and Discussion-Prevention and Mitigation of ARD}

The primary approach to the prevention and mitigation of ARD is to minimize the supply of the primary reactants for sulfide oxidation, and/or maximize the amount and availability of acid-neutralizing reactants. These methods involve minimizing oxygen supply through decreasing oxygen diffusion or advection/convection, minimizing water infiltration and leaching (water acts as both a reactant and a transport mechanism), minimizing, removing, or isolating sulfide minerals, maximizing availability of acid neutralizing minerals and pore water alkalinity and controlling bacteria and biogeochemical processes. All of these actions control the pore water $\mathrm{pH}$ and its resulting metal leaching. In the case of water minimization, not only does it control the formation of ARD, but it also limits ARD and leached metals from being transported from the mine waste. Another prevention option is to remove the source, i.e., Fe sulfides, from the mining wastes with the aim to reduce the total amount of ARD-producing waste and remediation efforts needed. Desulfurisation has been considered for some time as an alternative method to avoid formation of ARD [2]. The depyritized tailings must have so low sulfide content that they are not acid generating. Depyritised tailings could potentially be used as cover on other waste [2]. In the Minerals to Metal Initiative developed in South Africa [11] the desulfurization approach is developed in a systematic way. It is suggested that the main problem, the Fe sulfides, should not be spread out in tailings deposits as is the common practice today. The Fe sulfides should be concentrated, back-filled in mines, or deposited separately (e.g., [12]). Since pyrite may have relatively high concentrations of trace elements such as $\mathrm{Au}, \mathrm{Co}$ and $\mathrm{Cu}[13,14]$, and pyrite oxidation is a strongly exothermic reaction, another option is that metals and heat potentially could be extracted from these sulfides, today generally considered as problems and waste.

Mine waste needs to be managed using principles that control the environmental impact in both short and long term, as well as meeting the safety requirements on the deposits over long periods of time. While a certain impact on the local environment by disposal of significant amounts of mine wastes within the mine site is inevitable, the impact on the surroundings needs to be minimized. This waste minimization places high demands on mine operations management, and requires the use of appropriate waste disposal methods and ARD remediation.

A factor of particular importance is the need for methods that ensure safe disposal over very long periods of time. Neutralizing ARD by liming is common, but is a short-term solution that results in increased amounts of waste, although of another type [2]. Also other types of treatments of drainage waters from waste piles must be considered as short-term solutions. The environmental authorities and 
the mining industry in the Nordic countries for instance instead prefer remediation methods that last for very long times with a minimum of maintenance.

Prevention of ARD can be achieved through a risk-based planning and design approach that is applied throughout the mine-life cycle, but prevention is primarily planned and organized in the assessment and design phases and implemented during mine operations. The prevention process aims to quantify the long-term impacts of alternatives and to use this knowledge to select the option that has the least impact. Mitigation measures implemented as part of an effective control strategy should require minimal active intervention and management.

In general, more options and more effective options are available earlier in the mine life, as indicated in Figure 1 [2]. A thorough characterization of ore and waste should be performed at an early stage. A detailed knowledge of mineralogical composition, chemical composition and physical properties such as grain size, porosity and hydraulic conductivity of the different waste types is necessary for reliable predictions of ARD formation and efficiency of mitigation measures [2]. Different types of static and kinetic leaching tests are important in this context $[2,15]$. More than one measure, or a combination of measures, may be required to achieve the desired objective. Sites that generate ARD with a high solute load and concentrations of contaminants can incur significant long-term ARD treatment costs that can impair the economic success and, in some cases, the viability of a project. Measures for ARD prevention, mitigation, and treatment must therefore be included in evaluation of mine lifecycle costs. The result of this overall assessment may be a decision not to mine a particular rock mass at some mines, or to mine in a manner that might initially be thought to be more costly [16].

Figure 1. Options and Effectiveness with Time (TEAM NT, 2004) [2].

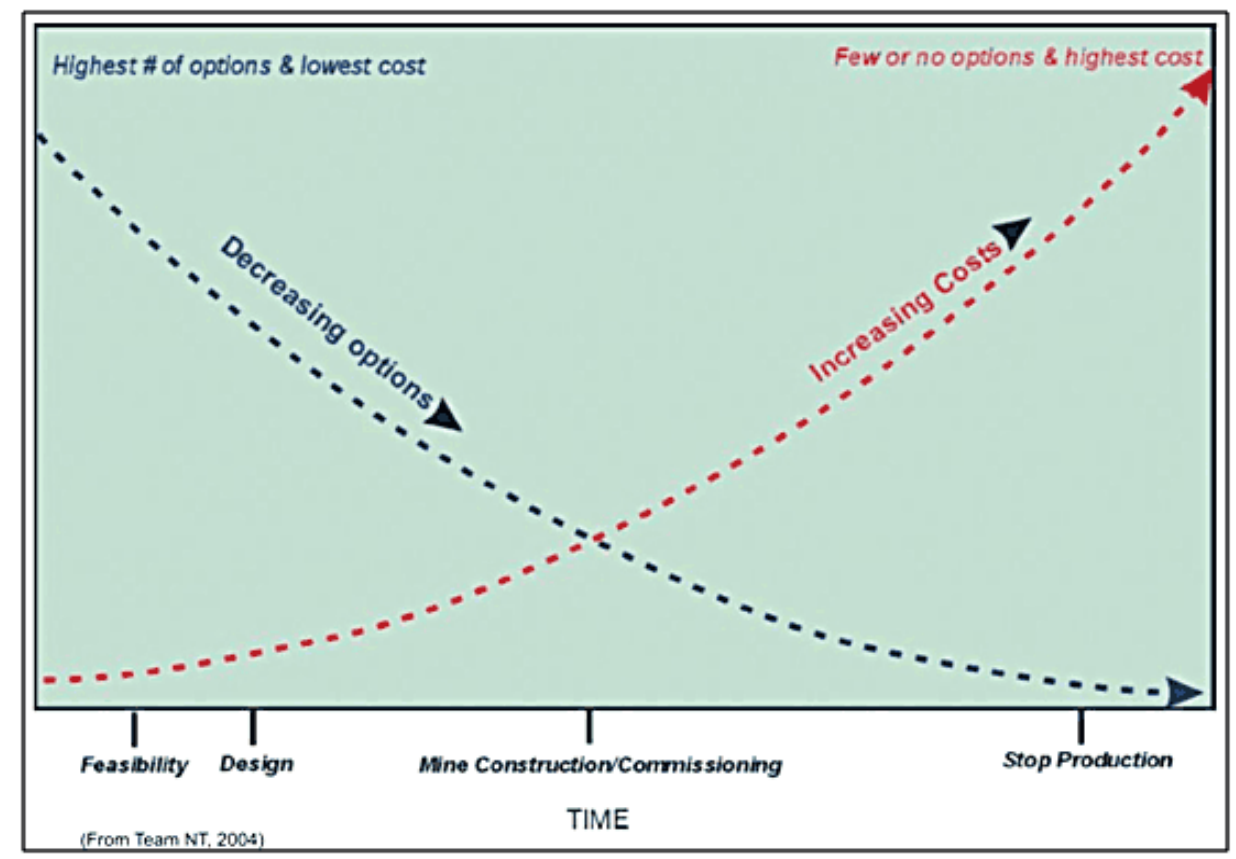

Early avoidance of ARD problems is a best practice technique that may be achieved through integrating the results of characterization and prediction with mine planning, design and waste management strategies. 


\subsection{ARD Prevention and Mitigation Best Practices}

A summary of the methods available for prevention and mitigation of mine drainage is shown in Figure 2. Detailed design manuals that were used in the compilation of these methods, such as [1,2,17-20] are listed in the references. All methods are site specific and need robust and flexible ARD prevention planning based on characterization and ARD prediction of the wastes in the early stage of the mine life.

Figure 2. Methods for Prevention and Mitigation of acid rock drainage (ARD) [2].

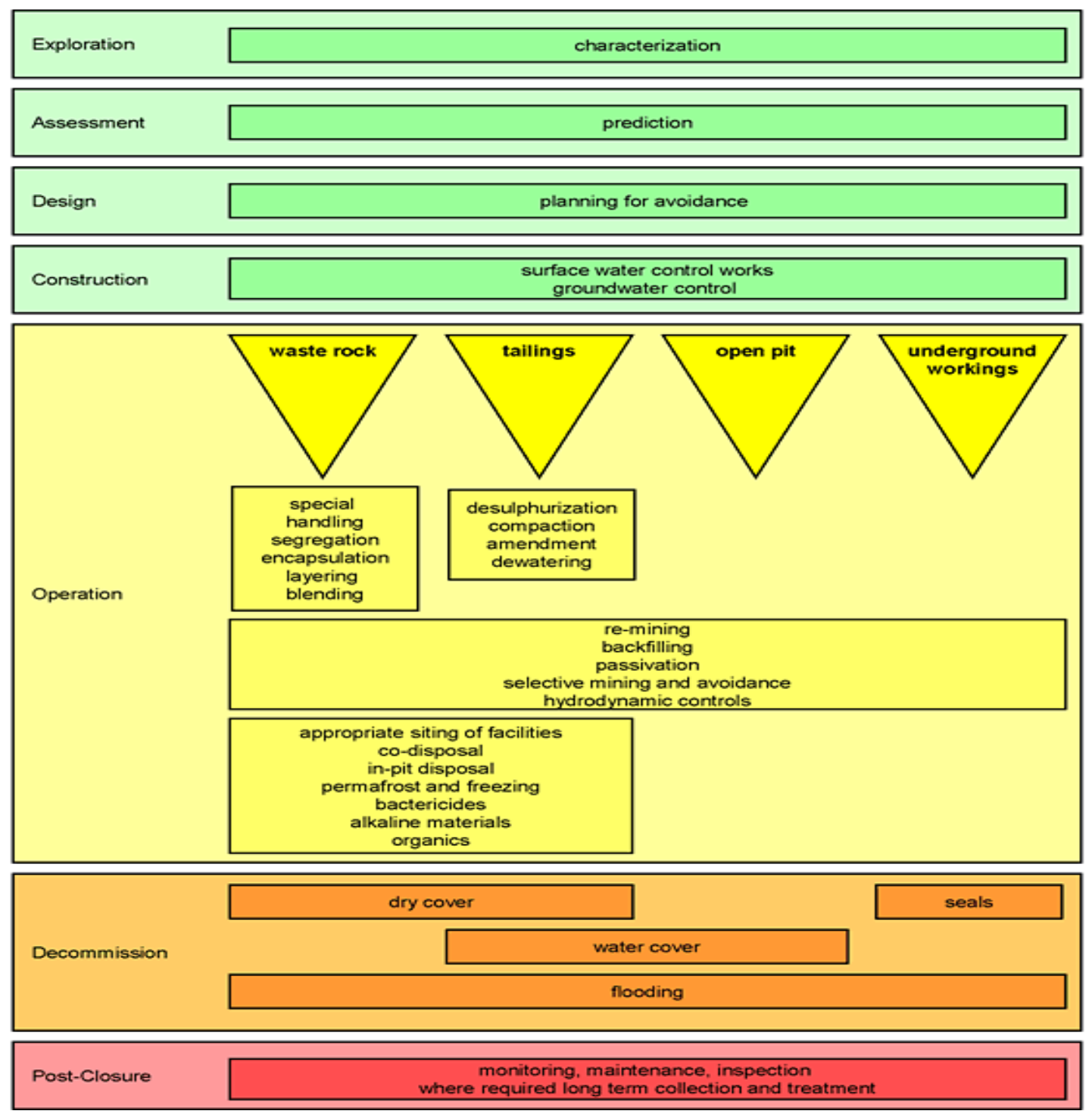

During operation there is a need for reducing the environmental impact until the final remediation during mine closure. Proven preventative best practices include avoidance of acid producing minerals, re-mining of sulfide- and metal-rich wastes, special handling and segregation of sulfide-rich wastes. Mine-waste handling may be incorporated into mine planning to minimize exposure of materials to atmospheric conditions and minimize the volume of material left on the surface at closure. Examples of common practices used in integrating the ARD management plan into mine operations include the following: 
- minimize the volume of sulfide waste by selective mining or sulfide-removal process steps so it can be adequately and cost effectively isolated from the environment.

- Encapsulation of the reactive tailings

- Mixing of tailings and reactive waste rock to minimize the oxygen ingress into the waste rock. This has been shown to be particularly effective when the tailings are dried to a paste form and mixed with the waste rock in cells or pits.

- Avoidance of placing waste storage facilities near sensitive receiving environments or regionally significant aquifers or recharge areas.

- Isolate waste repositories from uncontaminated surface waters through diversion ditches and dams.

- Isolate or segregate highly sulfide-rich tailings or mine waste using alkaline materials, covers, sub-aqueous disposal.

At mine closure, additional remediation efforts are often required such as water cover or dry covers. Different types of dry covers are often used to reduce the amount of oxygen reaching the waste. The most common methods are to apply dry covers consisting of several layers, usually including various soil types [1,2,17-19]. Both dry cover and water cover are based on the fact that the solubility and diffusivity of oxygen are much lower in water than in air. Dry covers, therefore, in most cases contain a sealing layer with low hydraulic conductivity, which is aimed at having a high degree of water saturation. The sealing layer then functions as a barrier against oxygen and water intrusion also in the cases when the groundwater surface is far below the cover. A protective layer is usually applied above the sealing layer to resist root penetration, freeze/thaw effects, drying etc. A type of dry cover often used by the Nordic mining industry consists of a sealing layer of clayey till with low hydraulic conductivity, and on top of that a protection layer of unclassified till. Modeling based on extensive lab- and field studies showed that the oxygen flux through this type of dry cover will be about one mole $\mathrm{O}_{2} / \mathrm{m}^{2}$ per year, a very strong reduction compared to pre-remediation conditions [1]. Also other materials such as cement-stabilized fly ash and organic waste (paper mill sludge and sewage sludge) have been used as sealing layers [2]. Sewage sludge has commonly been used for establishment of vegetation, but it has not often been used as a conventional barrier. Subaqueous disposal of reactive wastes in mine voids may be efficient, including placing mining wastes into open pits and underground workings. This method is particularly effective when the workings are flooded as the ground water recovers. The economic feasibility of this practice is highly site specific, but is fairly common, and the approaches are well developed. Mined-out pits can provide a void for storage of tailings, waste rock, or seepage water. Pits provide the potential for long-term geologically stable containment while traditional impoundments often require monitoring and maintenance to ensure stability of the constructed dam walls over the long term. In-pit disposal of tailings or waste rock may be combined with other strategies, such as subaqueous or underwater disposal, alkaline addition, cover technologies, and sulfate reduction. Water covers are often constructed by raising the dikes of tailings impoundments. However, this cannot be considered as a "walk away solution" without long time scale maintenance or supervision of the earthen dams, as demanded by the Swedish Environmental Protection Agency for instance with their "next ice age perspective". When functioning as planned, both dry and water covers slow down sulfide oxidation to an acceptable rate, resulting in that oxidation proceeds for very long times. However, 
there are risks for failures causing increased oxidation rates. According to the current policy of the Swedish Environmental Protection Agency, as an example, it is extremely difficult to get a permit to use natural lakes for disposal of mine waste, which otherwise in many aspects is the best solution.

The Figure 3 illustrates adaptive management and implementation using a phased approach, which begins with the development of hypotheses and conceptual designs based on site characterization and problem definition. The phased process can begin and enter at any stage of mine development. The key step is to develop a system design that leads to the basis for analysis and the capacity to make decisions. The process should include a staged approach that allows ongoing analysis, verification, and improvement in system design. Regional and local experience at nearby mines, where available, should also be used to minimize redundant investigations and to optimize the most successful methods for prevention and control. The phased approach leads to development of a monitoring and maintenance program that reinforces and improves system design.

Figure 3. Adaptive Management Implementation by Phased Approach (from [2]).

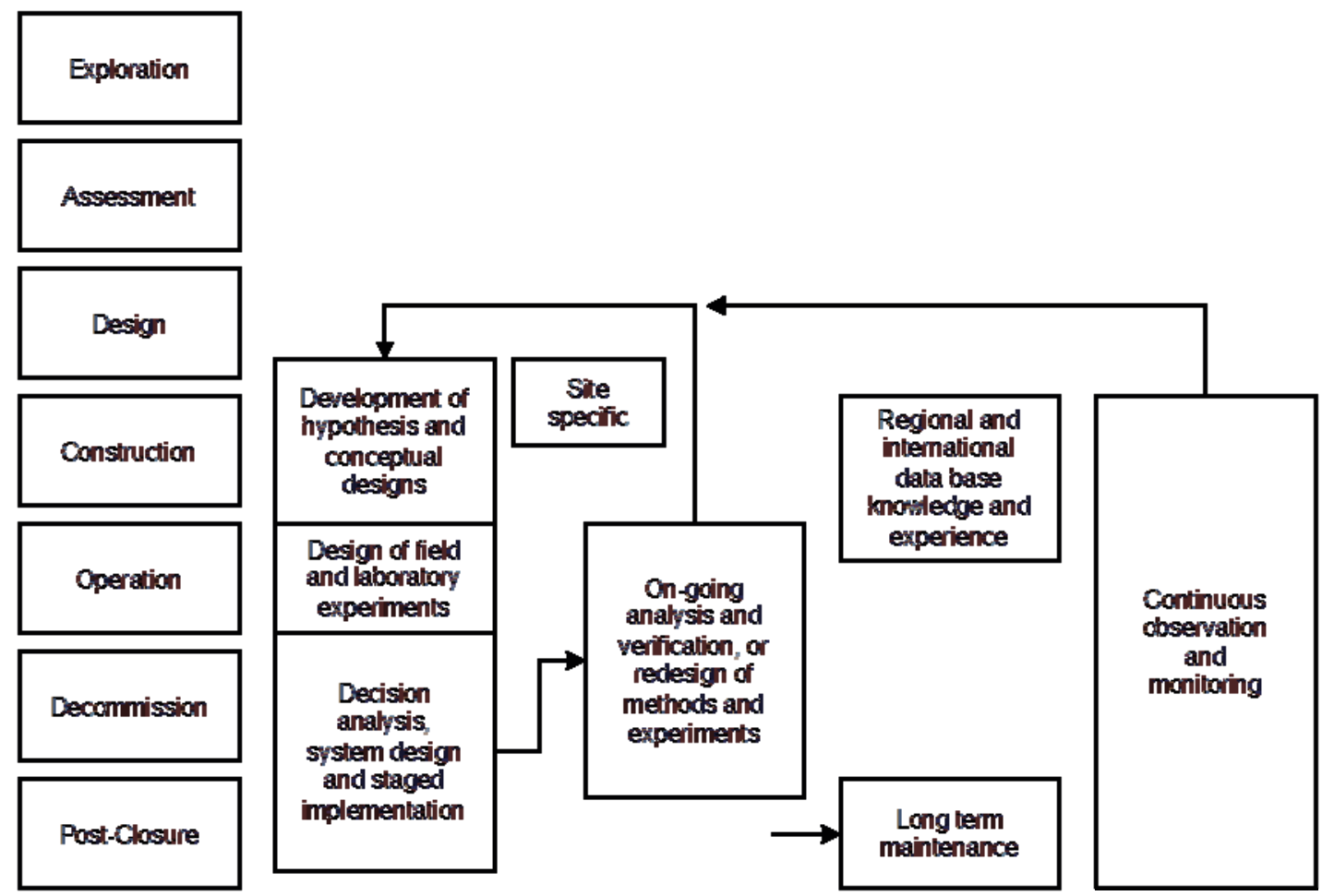

\subsection{Engaging Stakeholders}

The proceeding sections addressed many of the technical aspects of ARD prevention and mitigation, but for this ARD prevention effort to be truly successful all of the stakeholders must "buy in" on the strategy and approach. To achieve this agreement, the mine stakeholders (regulators, community leaders, NGOs, lenders, governmental agencies, as well as the mine operators) must be engaged early in the decision process. Their expectations and perceptions must be heard and addressed so that they feel the ARD management plan contains much of their thoughts and decisions. At many mine sites there is a small, vocal group of antagonist that do not want a mine regardless of the value to the majority in taxes, jobs and economic well-being of the community. They only way that these antagonists can be answered is to be totally transparent and honest in the engagement process of 
listening, acknowledging, consulting, accepting and partnering with the stakeholders to produce an acceptable and effective ARD management and mine closure plan. The stakeholder engagement process should start early, involve key company management and be totally transparent for it to be successful.

\subsection{Historical Mine Waste}

Although metal emissions from mines under operation are generally low, leaching of metals from existing mining residues is a large problem. Effluents from historical mining represent an important environmental problem [5]. Strategies for remediation of existing waste deposits may differ somewhat from plans for future waste deposits. Waste deposits without cover have been exposed for oxidation, resulting in that they contain weathering products, secondarily retained within the deposits. In addition, if such waste deposits are isolated from oxygen entrance, $\mathrm{Fe}^{3+}$ may function an oxidant [1].

Several remediation options are possible for existing, ARD-producing waste [2]. Strategies are site specific and should be based on thorough characterisation of mineralogy, chemical composition and physical properties as well as of local geology and hydrology. Re-mining is one option, resulting in metal recovery and potential possibilities to store the processed waste in controlled tailings impoundments. Accelerated leaching by controlled bioleaching is another possibility to recover metals and reduce the amount of reactive sulfides in the waste. Mixing the waste with acid neutralising agents may be a way to reduce the weathering rate. These neutralising agents could be alkaline rest products from other industries, such as steel and paper industries. Soil cover or water cover may be applied also in the case of old waste deposits, but it is important to consider secondary effects such as wash out of old weathering products and of $\mathrm{Fe}^{3+}$ as oxidant [1,2]. During a limited time period, it may therefore be necessary to combine the covers with active treatment of drainage waters. Typical treatments are to neutralise the drainage by using lime or alkaline rest products from other industries, or to use permeable, reactive barriers $[21,22]$.

\section{Conclusions}

ARD is a significant and potentially enduring environmental problem of the mining industry that could potentally be the industries most lasting and harmful legacy. Therefore, integrating an ARD management plan into the actual mine operations in the early phases of exploration, continuing through the mine life until final closure might be succesful and decrease the environmental impact. Hence, it needs the commitment of the full mine operations team from mine planners to the mine manager, and it must be fully integrated into the mine economic model as well as operations early in the mine-life cycle. It should not be implemented as an after thought at closure when much of the human, financial and mechanical resourses are gone. A thorough characterization of ore and waste should be performed at an early stage. A detailed knowledge of mineralogical composition, chemical composition and physical properties such as grain size, porosity and hydraulic conductivity of the different waste types is necessary for reliable predictions of ARD formation and efficiency of mitigation measures. Best-practices methods for the prevention and mitigation of ARD should always be used. Another key element of successfully planning to prevent ARD and to close a mining operation is to engage the mine stakeholders (regulators, community and government leaders, NGOs and lenders) in helping develop and implement the ARD management plan. This engagement effort recognizes stakeholder concerns 
and perceptions and creates a partnership between the mine operator and the mine stakeholders in both the operation and closure of the mine.

\section{Acknowledgments}

In this paper we have mainly used material from the GARD Guide, and the authors wish to thank INAP member companies for their support to producing the GARD Guide. We have also used results from the Swedish MiMi-programme, financed by MISTRA.

\section{References}

1. Höglund, L.-O.; Herbert, R.; Lövgren, L.; Öhlander, B.; Neretniks, I.; Moreno, L.; Malmström, M.; Elander, P.; Lindvall, M.; Lindström, B. MiMi-Performance Assessment, Main Report, MiMi-Report 2003:3; Moreno, Italy, 2004; ISSN 1403-9478, ISBN 91-89350-27-8.

2. The global acid rock drainage guide (GARD Guide). Development of the Global Acid Rock Drainage Guide; International Network for Acid Drainage (INAP): Richmond, BC, Canada, 2011. Available online: http://www.gardguide.com (accessed on 20 December 2011).

3. Franklin, J.M.; Gibson, H.L.; Jonasson, I.R.; Galley, A.G. Volcanogenic massive sulfide deposits. In Economic Geology, One Hundredth Anniversary Volume; Hedenquist, W., Thompson, J.F.H., Goldfarb, R.J., Richards, J.P., Eds.; Society of Economic Geologists, INC.: Pretoria, South Africa, 2005; pp. 523-560.

4. Seedorf, E.; Dilles, J.H; Proffet, J.M., Jr.; Einaudi, M.T.; Zurcher, L.; Stavast, W.J.A.; Johnson, D.A.; Barton, M.D. Porphyry deposits: Characteristics and origin of hypogene features. In Economic Geology, One Hundredth Anniversary Volume; Hedenquist, J.W., Thompson, J.F.H., Goldfarb, R.J., Richards, J.P., Eds.; Society of Economic Geologists, INC.: Littleton, CO, USA, 2005; pp. 251-298.

5. Lottermoser, B. Mine Wastes, Characterization, Treatment and Environmental Impacts; Springer-Verlag: Berlin, Germany, 2010.

6. Blowes, D.W.; Ptacek, C.J.; Jurjovec, J. Mill tailings: Hydrogeology and geochemistry. In Environmental Aspects of Mine Wastes, Short Course Series Vol. 31, Mineralogical Association of Canada; Jambor, J.L., Blowes, D.W., Ritchie, A.I.M., Eds.; Mineralogical Association of Canada: Nepean, ON, Canada, 2003; pp. 95-116.

7. Nordstrom, D.K. Effects of microbiological and geochemical interactions in mine drainage. In Environmental Aspects of Mine Wastes, Short Course Series Vol. 31, Mineralogical Association of Canada; Jambor, J.L., Blowes, D.W., Ritchie, A.I.M., Eds.; Mineralogical Association of Canada: Nepean, ON, Canada, 2003; pp. 227-238.

8. Ritchie, A.I.M. Oxidation and gas transport in piles of sulfidic material. In Environmental Aspects of Mine Wastes, Short Course Series Vol. 31, Mineralogical Association of Canada; Jambor, J.L., Blowes, D.W., Ritchie, A.I.M., Eds.; Mineralogical Association of Canada: Nepean, ON, Canada, 2003; pp. 73-94.

9. Holmström, H.; Salmon, U.J.; Carlsson, E.; Petrov, P.; Öhlander, B. Geochemical investigations of sulphide-bearing tailings at Kristineberg, northern Sweden, a few years after remediation. Sci. Total Environ. 2001, 273, 111-133. 
10. Ljungberg, J.; Öhlander, B. The geochemical dynamics of oxidizing mine tailings at Laver, northern Sweden. J. Geochem. Explor. 2001, 74, 57-72.

11. Minerals to Metal Initiative; University of Cape Town: Cape Town, South Africa, 2009. Available online: http://www.mineralstometals.uct.ac.za (accessed on 3 December 2011).

12. Hesketh, A.H.; Broadhurst, J.L.; Harrison, S.T.L. Mitigating the generation of acid mine drainage from copper sulfide tailings impoundments in perpetuity: A case study for an integrated management strategy. Miner. Eng. 2010, 23, 225-229.

13. Fleischer, M. Minor elements in some sulfide minerals. Econ. Geol. 1955, Fiftieth Anniversary, 970-1024.

14. Large, R.L.; Danyushevsky, L.; Hollit, C.; Maslennikov, V.; Meffre, S.; Gilbert, S. Gold and trace element zonation in pyrite using a laser imaging technique: Implications for the timing of gold in orogenic and Carlin-style sediment-hosted deposits. Econ. Geol. 2009, 104, 635-668.

15. Price, W.A. Draft Guidelines and Recommended methods for the Prediction of Metal Leaching and Acid Rock Drainage at Minesites in British Columbia; Reclamation Section, Energy and Minerals Division, Ministry of Employment and Investment: Smithers, BC, USA, 1997.

16. Acid Drainage Technology Initiative (ADTI); National Land Reclamation Centre, West Virginia University: Morgantown, WV, USA, 1998.

17. Tremblay, C.; Hogan, C.M. Prevention and Control. Manual 5.4.2d G.A; Mine Environment Neutral Drainage Program (MEND), The Canada Center for Mineral and Energy Technology (CANMET): Ottawa, ON, Canada, 2001; Volume 6.

18. Design, Construction and Performance Monitoring of Cover Systems for Waste Rock and Tailings; Mine Environment Neutral Drainage Program (MEND), Report 2.21.4; Natural Resources Canada, O'Kane Consultants Inc.: Saskatoon, SK, Canada, 2004.

19. Macro-Scale Cover Design and Performance Monitoring Manual 2007; Mine Environment Neutral Drainage Program (MEND), Report 2.21.5; Natural Resources Canada, O'Kane Consultants Inc.: Saskatoon, SK, Canada, 2007.

20. Best Practice Guideline-H2: Pollution Prevention and Minimization of Impacts; Department of Water and Forestry, Republic of South Africa (DWAF): Pretoria, South Africa, 2007.

21. Benner, S.G.; Blowes, D.W.; Ptacek, C.J.; Mayer, K.U. Rates of sulfide reduction and metal sulfide precipitation in a permeable reactive barrier. Appl. Geochem. 2002, 17, 301-320.

22. Younger, P.L.; Banwart, S.A.; Hedin, R.S. Mine Water: Hydrology, Pollution, Remediation; Kluwer Academic Publishers: Dordrecht, The Netherlands, 2002.

(C) 2012 by the authors; licensee MDPI, Basel, Switzerland. This article is an open access article distributed under the terms and conditions of the Creative Commons Attribution license (http://creativecommons.org/licenses/by/3.0/). 